\title{
Combination era, using combined vasopressors showed benefits in treating septic shock patients: a network meta-analysis of randomized controlled trials
}

\author{
Chongxiang Chen ${ }^{1,2 \#}$, Lanlan Pang ${ }^{3 \#}$, Yanyan Wang ${ }^{3 \#}$, Tianmeng $\mathrm{Wen}^{4}$, Wu Yu ${ }^{3}$, Xiaolei Yue ${ }^{3}$, Yuming \\ Rong $^{2}$, Wei Liao ${ }^{2}$
}

${ }^{1}$ Guangzhou Institute of Respiratory Diseases, the First Affiliated Hospital of Guangzhou Medical University, State Key Laboratory of Respiratory Disease, Guangzhou 510120, China; ${ }^{2}$ Department of Intensive Care Unit, Sun Yat-sen University Cancer Center, State Key Laboratory of Oncology in South China, Collaborative Innovation Center for Cancer Medicine, Guangzhou 510060, China; ${ }^{3}$ Zhongshan School of Medicine, ${ }^{4}$ School of Public Health, Sun Yat-sen University, Guangzhou 510275, China

Contributions: (I) Conception and design: C Chen; (II) Administrative support: None; (III) Provision of study materials or patients: None; (IV) Collection and assembly of data: C Chen, T Wen; (V) Data analysis and interpretation: C Chen; (VI) Manuscript writing: All authors; (VII) Final approval of manuscript: All authors.

\#These authors contributed equally to this work.

Correspondence to: Wei Liao; Yuming Rong. Department of Intensive Care Unit, Sun Yat-sen University Cancer Center, State Key Laboratory of Oncology in South China, Collaborative Innovation Center for Cancer Medicine, Guangzhou 510060, China.

Email: liaowei1631@163.com; rongym@sysucc.org.cn.

Background: Septic shock is one of the major healthcare problems, affecting millions of people around the world every year. The object of this study is to find the best kind of regimen of vasopressors treatment in septic shock.

Methods: The PubMed, and the Web of Science were used to find the included studies. Stata 15.1 was performed to this systemic review and network meta-analysis.

Results: After searching and screening the articles, finally we included articles about 31 randomized controlled trials (RCTs), 11 arms (dopamine, dopexamine, epinephrine, norepinephrine, norepinephrine + dobutamine, norepinephrine + dopexamine, norepinephrine + epinephrine, norepinephrine + vasopressin, phenylephrine, terlipressin, vasopressin) and total 5,928 patients with septic shock. Compared with dopamine, the regimens (epinephrine, norepinephrine, norepinephrine + dobutamine, and vasopressin) have significantly lower 28-day mortality. Ranking the regimens in the order of estimated probabilities of each treatment by using the network meta-analysis for 28-day mortality, the result showed that norepinephrine + dopexamine was the best one (57.3\%), followed by norepinephrine + epinephrine (14.8\%), norepinephrine + dobutamine $(10.9 \%)$, dopexamine $(11.2 \%)$, terlipressin $(9.8 \%)$, norepinephrine + vasopressin $(2.4 \%)$, phenylephrine $(1.2 \%)$, epinephrine $(1.0 \%)$, vasopressin $(0.5 \%)$, norepinephrine $(0.0 \%)$, and dopamine $(0.0 \%)$. In addition, for the results of arrhythmia and increased heart rate, the combination regimens groups did not showed inferiority to other single regimen groups.

Conclusions: Single dopamine had significantly higher $28 \mathrm{~d}$ mortality. Combination regimens of vasopressors accounted for the best three therapeutic regimens. In treating patients with septic shock, using combining regimens probably gets more benefits.

Keywords: Septic shock; vasopressor; norepinephrine

Submitted Jun 01, 2019. Accepted for publication Sep 16, 2019.

doi: 10.21037/atm.2019.09.134

View this article at: http://dx.doi.org/10.21037/atm.2019.09.134 


\section{Introduction}

In the latest definitions for sepsis and septic shock (Sepsis-3), Sepsis is defined as life-threatening organ dysfunction caused by a dysregulated host response to the infection. Septic shock is a subset of sepsis with circulatory and cellular/metabolic dysfunction associated with a higher risk of mortality (1-3). Nowadays, septic shock is one of the major healthcare problems, affecting and killing millions of people around the world every year $(4,5)$. Similar to acute myocardial infarction, or stroke, early identification and appropriate management in the initial hours after sepsis developing can improve the prognosis.

In septic shock, when volume resuscitation fails to restore mean arterial pressure (MAP), vasopressors such as dopamine, norepinephrine, epinephrine, dopexamine, will be used, either alone or in combination $(6,7)$.

There have been some meta-analysis studies for comparing these vasopressors in 28-day mortality (8-13). The result of these studies showed that norepinephrine was probably the best regimen. The latest network meta-analysis was published in May 2019. In the meta-analysis conducted by Cheng et al. (14), the studies comparing levosimendan with comparators were included in their study, however, levosimendan promotes the vasodilatation (15), which is different from the vasopressors in the management of septic shock. Actually in those included studies (16-24), they not only used single levosimendan as a group [norepinephrine (16-21,23), or dopamine (22) was also added to maintain the blood pressure]. Moreover, three randomized controlled trials (RCTs) included in their study combined placebo with/using other standard therapy as a group (25-27). So in our study, we excluded the studies above, and mainly talked about "vasopressor". We did this network meta-analysis and tried to find out what kind of regimens of vasopressors could be more appropriate for treating patients with septic shock in clinical practice.

\section{Methods}

\section{Search strategy}

Two investigators independently reviewed the identified abstracts and selected articles for full reviewing, and the discrepancies were resolved by the third reviewer. The reference lists of eligible studies and relevant papers were also manually searched and reviewed. The search terms were "septic shock" and "vasopressor", etc. The search terminal date was 2019/4/22. Finally we found 2,517 articles, excluding 1,374 duplications, then we included 46 articles through reading the title and abstract, and 31 studies (28-39) were (40-58) included by reading the whole articles (Figure 1).

\section{Inclusion and exclusion}

Inclusions contain: (I) researched study about using vasopressors for treating septic shock; (II) outcome: 28-day mortality; (III) only be published in English.

Exclusions contain: (I) review, retrospective research, case report; (II) insufficient data in the articles.

\section{Data elected}

Two authors independently reviewed the identified abstracts and selected articles to full review. The third reviewer addressed the discrepancies. For each selected publication, the following baselines and study characteristics were extracted: first author, publication year, country, participant characteristics, total number of patients in experiment and control group, age of patients in each group, other baseline characteristics, and the treatment dose of each medication in these studies were concluded below (Tables 1,S1). Primary outcome measure was the 28-day mortality, secondary outcome measures were the incidence of arrhythmia, and increased heart rate. This study is a network meta-analysis, so it does not need ethics approval.

\section{Risk of bias assessment}

Risk of bias of trials included in this meta-analysis was assessed according to the Jadad scale, in the following domains: random sequence generation, allocation concealment, blinding of participants and personnel, and completed withdrawals and dropouts.

\section{Statistical analysis}

We pooled data and used odd ratios (OR), confidential interval (CI) for the dichotomy outcome: the 28-day mortality, incidence of arrhythmia. We used mean difference (MD), CI for the continuous outcome: heart rate. All statistical analyses were carried out with Stata 15.1.

\section{Results}

In our study, we totally included 31 RCTs with 5928 


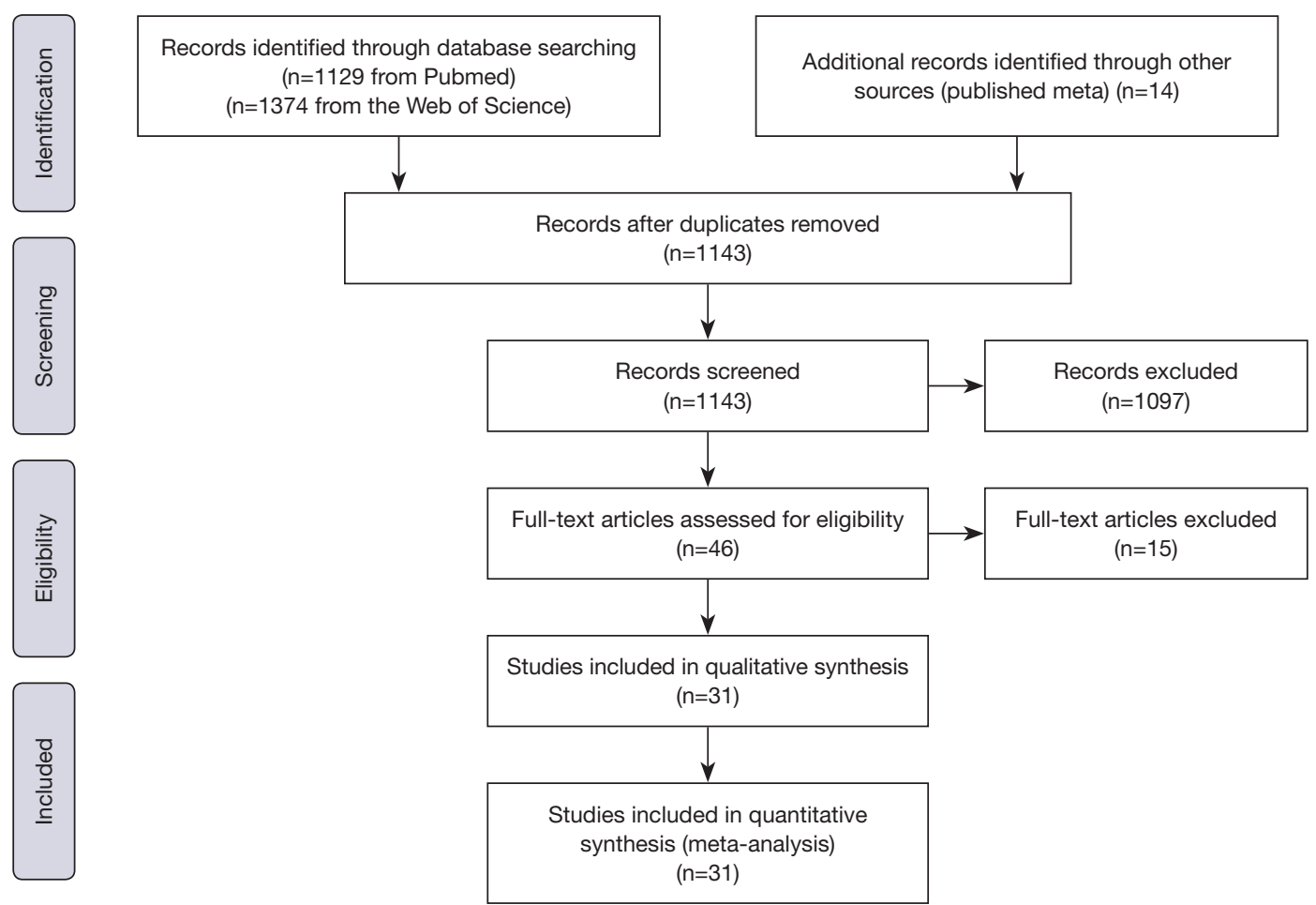

Figure 1 Flow diagram of choosing the appropriated articles.

patients about what kind of regimens of vasopressors could decrease the 28-day mortality in patients with septic shock. The quality of the article evaluations was as followed. The Jadad Scales of all included studies ranged from 2 to 7 , and the studies included in our study were all well-prepared RCTs (Table 1).

In network meta-analysis, we didn't compare the heterogeneity in the study, but we made an inconsistency test to find out whether the data of these studies could be mixed and calculated. The inconsistency test showed that the comparison could be performed by consistency $(\mathrm{P}>0.05)$ (Table 2).

Network evidence of the comparisons for the different regimens of vasopressors was showed in Figure 2. Compared with dopamine, some therapeutic regimens (epinephrine (OR 0.560, 95\% CI: 0.330-0.948), norepinephrine (OR 0.803, 95\% CI: 0.655-0.986), norepinephrine +dobutamine (OR 0.454, 95\% CI: 0.232-0.887), vasopressin (OR 0.702, 95\% CI: $0.547-0.900)$ were more beneficial to decrease the $28 \mathrm{~d}$ mortality, respectively. However, there was no significant difference among these therapeutic regimens (Table 3, Figure 3).

In the rank of network meta-analysis, we found that norepinephrine + dopexamine $(57.3 \%)$ was the most effective therapeutic regimen to reduce the $28 \mathrm{~d}$ mortality in these patients with septic shock, followed by norepinephrine+ epinephrine (14.8\%), norepinephrine + dobutamine $(10.9 \%)$, dopexamine $(11.2 \%)$, terlipressin (9.8\%), norepinephrine + vasopressin (2.4\%), phenylephrine $(1.2 \%)$, epinephrine $(1.0 \%)$, vasopressin $(0.5 \%)$, norepinephrine $(0.0 \%)$, and dopamine $(0.0 \%)$. The biggest probability means this therapeutic regimen has the greatest chance to be the best treatment (Table 4).

Potential publication bias of vasopressors used for treating patients with septic shock was performed and showed as funnel plot (Figure 4).

Supplementary data show the results of incidence of arrhythmia and increased heart rate in septic shock patients in the included studies of the network meta-analysis (Figures S1,S2, Tables S1-S5).

\section{Discussion}

According to the results of our study, using combination vasoactive agent (vasopressors) is prior to only one agent. In addition, for the results of arrhythmia and increased heart 
Table 1 Baseline characteristics of enrolled studies

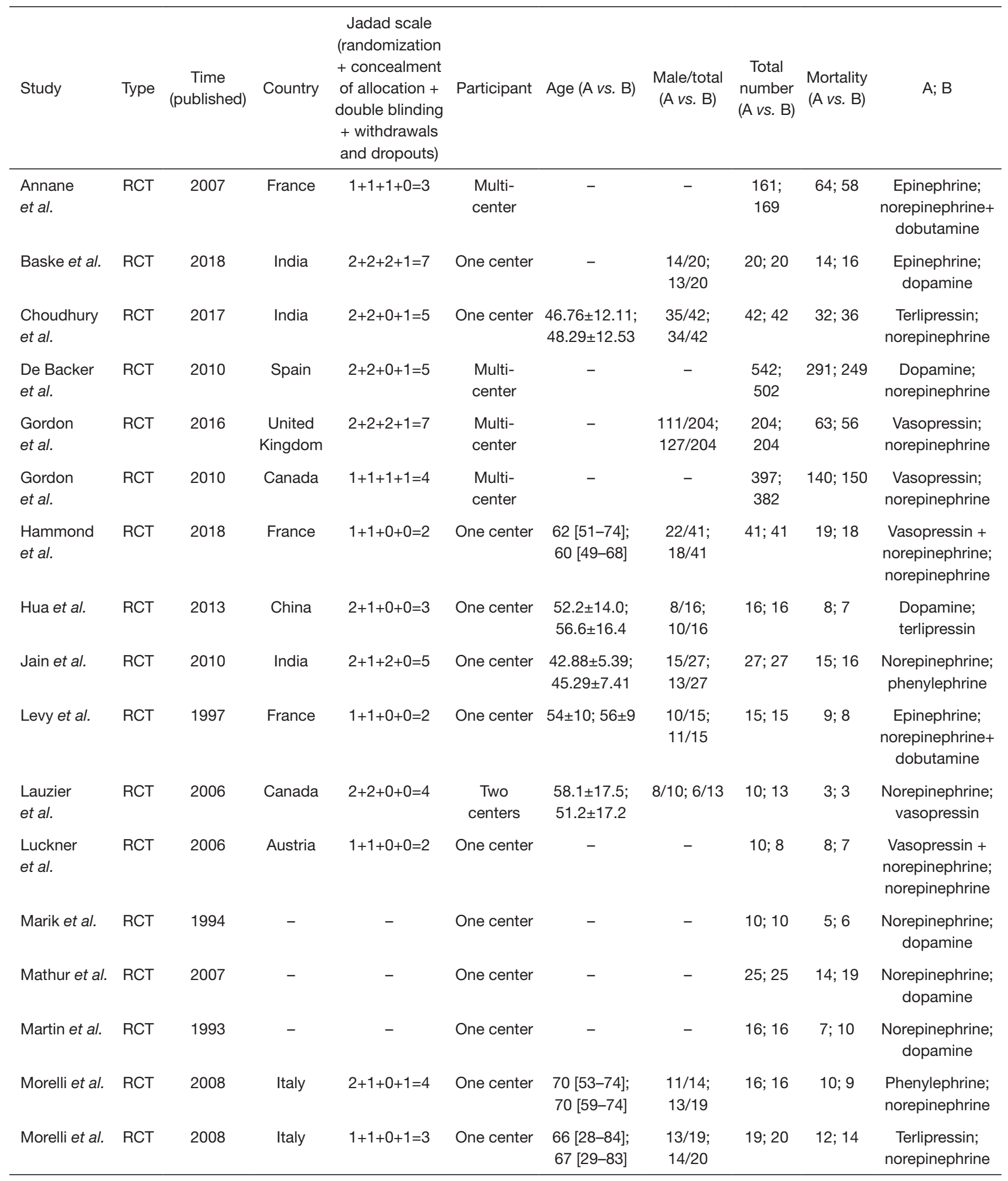

Table 1 (continued) 
Table 1 (continued)

\begin{tabular}{|c|c|c|c|c|c|c|c|c|c|c|}
\hline Study & Type & $\begin{array}{c}\text { Time } \\
\text { (published) }\end{array}$ & Country & $\begin{array}{l}\text { Jadad scale } \\
\text { (randomization } \\
+ \text { concealment } \\
\text { of allocation + } \\
\text { double blinding } \\
\text { + withdrawals } \\
\text { and dropouts) }\end{array}$ & Participant & Age (A vs. B) & $\begin{array}{l}\text { Male/total } \\
\text { (A vs. B) }\end{array}$ & $\begin{array}{c}\text { Total } \\
\text { number } \\
\text { (A vs. B) }\end{array}$ & $\begin{array}{l}\text { Mortality } \\
\text { (A vs. B) }\end{array}$ & $A ; B$ \\
\hline $\begin{array}{l}\text { Myburgh } \\
\text { et al. }\end{array}$ & $\mathrm{RCT}$ & 2008 & Australia & $2+2+2+1=7$ & $\begin{array}{l}\text { Mult- } \\
\text { center }\end{array}$ & $\begin{array}{l}59.4 \pm 15.9 \\
60.4 \pm 14.8\end{array}$ & $\begin{array}{c}10 / 64 \\
7 / 63\end{array}$ & $64 ; 63$ & $15 ; 17$ & $\begin{array}{c}\text { Epinephrine; } \\
\text { norepinephrine }\end{array}$ \\
\hline $\begin{array}{l}\text { Mahmoud } \\
\text { et al. }\end{array}$ & $\mathrm{RCT}$ & 2012 & Egypt & $2+2+2+0=6$ & One center & $\begin{array}{c}52.4 \pm 4.5 \\
50.3 \pm 6.5\end{array}$ & $\begin{array}{l}16 / 30 \\
15 / 30\end{array}$ & $30 ; 30$ & $15 ; 16$ & $\begin{array}{c}\text { Norepinephrine } \\
\text { + dobutamine; } \\
\text { norepinephrin + } \\
\text { epinephrine }\end{array}$ \\
\hline Mehta et al. & $\mathrm{RCT}$ & 2013 & Canada & $1+1+1+1=4$ & 9 centers & $\begin{array}{c}62.9 \\
{[51.2-73.6]} \\
65.5 \\
{[50.8-76.1]}\end{array}$ & $\begin{array}{l}43 / 65 \\
42 / 56\end{array}$ & $65 ; 56$ & $27 ; 24$ & $\begin{array}{c}\text { Vasopressin; } \\
\text { norepinephrine }\end{array}$ \\
\hline Patel et al. & $\mathrm{RCT}$ & 2010 & USA & $1+1+0+0=2$ & One center & - & $\begin{array}{l}64 / 134 \\
52 / 118\end{array}$ & $\begin{array}{l}134 \\
118\end{array}$ & $67 ; 51$ & $\begin{array}{c}\text { Dopamine; } \\
\text { norepinephrine }\end{array}$ \\
\hline $\begin{array}{l}\text { Ruokonen } \\
\text { et al. }\end{array}$ & $\mathrm{RCT}$ & 1993 & Finland & $1+1+0+0=2$ & One center & 18-76; 39-53 & - & $5 ; 5$ & $4 ; 3$ & $\begin{array}{c}\text { Norepinephrine; } \\
\text { dopamine }\end{array}$ \\
\hline $\begin{array}{l}\text { Ramaswamy } \\
\text { et al. }\end{array}$ & $\mathrm{RCT}$ & 2016 & India & $2+2+2+1=7$ & One center & $\begin{array}{l}7[1-11] \\
4[0.8-8]\end{array}$ & $\begin{array}{l}15 / 29 \\
15 / 31\end{array}$ & $29 ; 31$ & $14 ; 18$ & $\begin{array}{l}\text { Epinephrine; } \\
\text { dopamine }\end{array}$ \\
\hline Russell et al. & $\mathrm{RCT}$ & 2013 & Canada & $1+1+1+0=3$ & $\begin{array}{l}\text { Multi- } \\
\text { center }\end{array}$ & $\begin{array}{l}60.7 \pm 16.7 \\
60.0 \pm 15.7\end{array}$ & $\begin{array}{l}\text { 121/191; } \\
112 / 203\end{array}$ & $\begin{array}{l}191 \\
203\end{array}$ & $65 ; 60$ & $\begin{array}{c}\text { Norepinephrine; } \\
\text { vasopressin }\end{array}$ \\
\hline $\begin{array}{l}\text { Schmoelz } \\
\text { et al. }\end{array}$ & $\mathrm{RCT}$ & 2006 & Germany & $2+1+2+0=2$ & One center & $\begin{array}{c}49.24 \pm 19.03 \\
56.7 \pm 18.5\end{array}$ & $\begin{array}{l}14 / 22 \\
10 / 21\end{array}$ & $22 ; 21$ & $4 ; 5$ & $\begin{array}{l}\text { Dopamine; } \\
\text { dopexamine }\end{array}$ \\
\hline Seguin et al. & $\mathrm{RCT}$ & 2002 & France & $1+1+0+0=2$ & One center & $\begin{array}{l}65 \pm 12 \\
70 \pm 13\end{array}$ & $6 / 10 ; 6 / 11$ & $10 ; 11$ & $4 ; 5$ & $\begin{array}{c}\text { Epinephrine; } \\
\text { norepinephrine+ } \\
\text { dobutamine }\end{array}$ \\
\hline Seguin et al. & $\mathrm{RCT}$ & 2006 & France & $1+1+0+0=2$ & One center & $\begin{array}{l}67 \pm 13 \\
65 \pm 10\end{array}$ & - & $10 ; 12$ & $3 ; 2$ & $\begin{array}{c}\text { Epinephrine; } \\
\text { dopexamine + } \\
\text { norepinephrine }\end{array}$ \\
\hline Ventura et al. & $\mathrm{RCT}$ & 2015 & Brazil & $2+2+2+1=7$ & One center & $\begin{array}{c}39.6 \pm 46.3 \\
\text { months; } \\
56.9 \pm 58.2 \\
\text { months }\end{array}$ & $\begin{array}{l}35 / 63 \\
35 / 57\end{array}$ & $63 ; 57$ & $13 ; 4$ & $\begin{array}{l}\text { Dopamine; } \\
\text { epinephrine }\end{array}$ \\
\hline
\end{tabular}

$\mathrm{RCT}$, randomized controlled trial. 
Table 2 Network meta inconsistency test

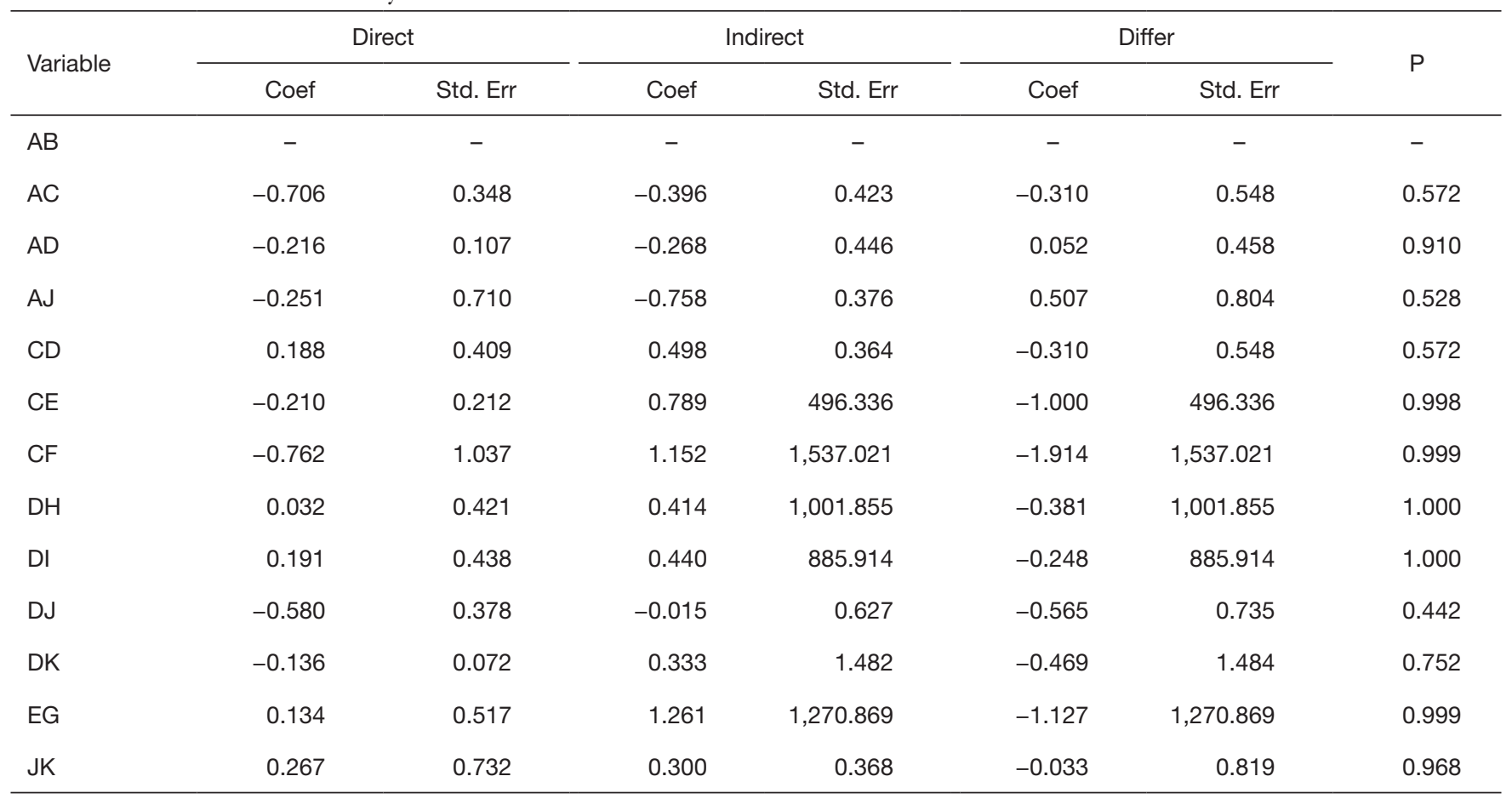

A, dopamine; B, dopexamine; C, epinephrine; D, norepinephrine; E, norepinephrine + dobutamine; F, norepinephrine + dopexamine; G, norepinephrine + epinephrine; H, norepinephrine + vasopressin; I, phenylephrine; J, terlipressin; K, vasopressin.

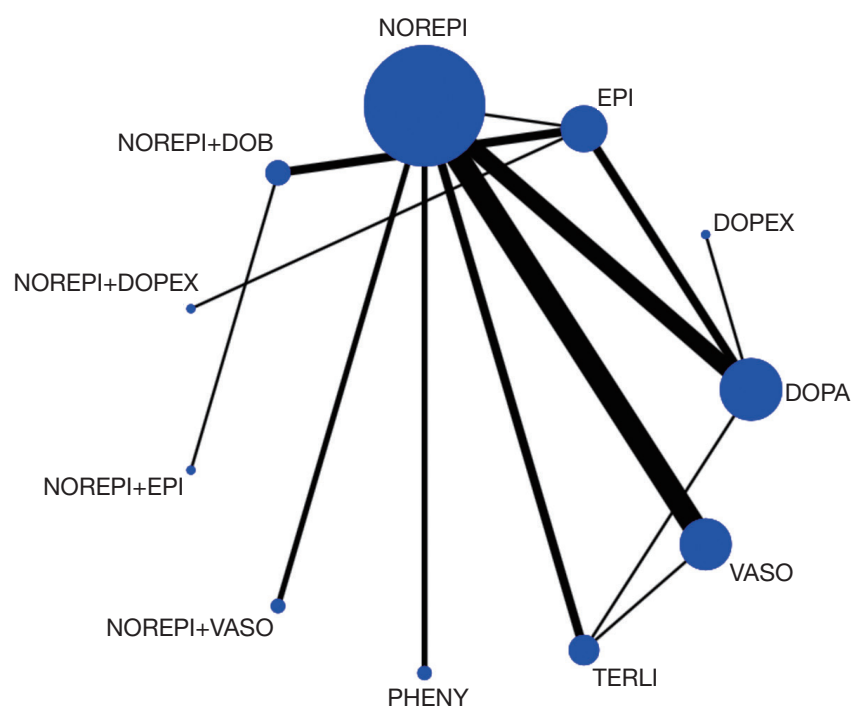

Figure 2 Network evidence of the comparisons for the different vasopressors regimens.

rate, the combination regimens groups did not showed inferiority to other single regimen groups.

Why using combination is more beneficial to patients with septic shock? The reasons should be derived from the composition of every combination regimen. We found out that every combination regimen contain norepinephrine, which mainly plays a role in the alpha adrenergic receptor in peripheral blood vessels, and some agents (epinephrine, dopexamine, dobutamine) increase the heart rate and stroke volume.

On the one hand, in pathophysiology, septic shock is a kind of distributive shock; the hypotension results from peripheral vasodilation and low systemic vascular resistance (59). Septic shock not only injures the vessel, making the body fluid flow from blood vessel to tissue, but also damages the cardiac function by secreting bacterial toxin $(60,61)$.

On the other hand, single vasopressor regimens have many adverse events. For example, epinephrine induces higher heart rate, cardiac output, oxygen delivery, and more oxygen consumption than the combinations by stimulating the beta-1 adrenergic receptors (6); dopamine increases MAP mostly due to increment of stroke volume and heart rate; Norepinephrine also has limitations, as it increases MAP by means of the vasoconstrictive effects, with little improvement of cardiac function, changing heart rate and increasing strike volume less; In recent studies, low dose of 
Table 3 Odd ratio of comparisons for the different vasopressors regimens

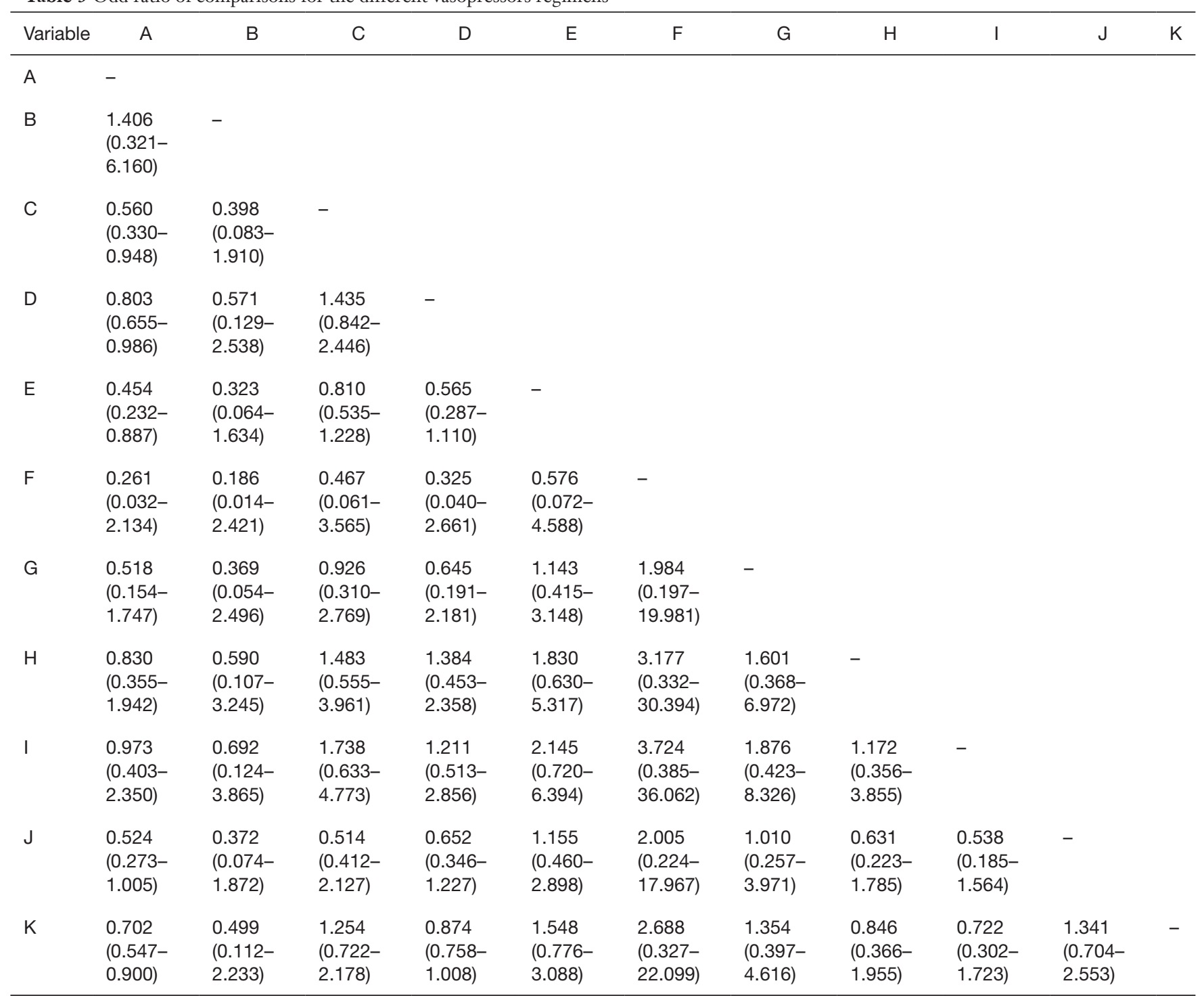

A, dopamine; B, dopexamine; C, epinephrine; D, norepinephrine; E, norepinephrine + dobutamine; F, norepinephrine + dopexamine; G, norepinephrine + epinephrine; H, norepinephrine + vasopressin; I, phenylephrine; J, terlipressin; K, vasopressin.

vasopressin is probably effective in raising blood pressure in patients refractory to other vasopressors and may have other potential physiologic benefits.

In addition, combination regimens probably have synergistic effects on decreasing the dosage and adverse events of one agent.

Similarly, the meta-analysis conducted by Zhou et al. (10) also showed the priority to combination regimens. However, the guideline (62) only demonstrated that norepinepherine was more useful than dopamine, and 'adding either vasopressin or epinephrine' to norepinepherine was suggested. Nowadays, in clinical practice, combinations only appear when single vasopressor treatment could not appropriately control the MAP.

The limitations of our study were showed as followed: Firstly, the studies included were only published in English, so we might lose some excellent studies published in other languages. Secondly, although the result showed that the probably best combination was norepinephrine and dopexamine. This finding was based on a single study 


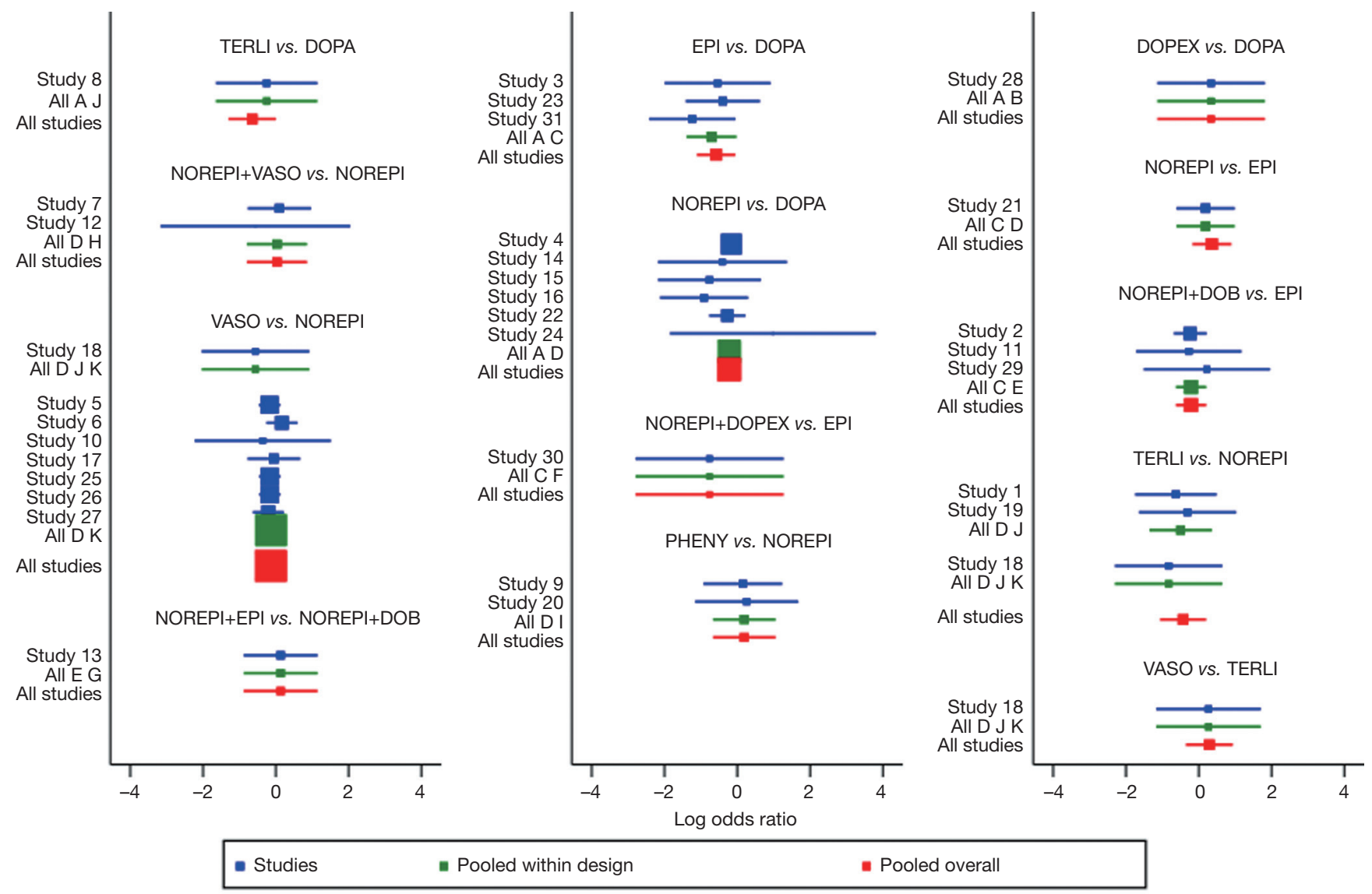

Test of consistency: chi2 (4) $=1.04, \mathrm{P}=0.904$

Figure 3 Forest plots of the comparisons for the different vasopressor regimens.

Table 4 Estimated probabilities (\%) of each treatment being the best

\begin{tabular}{lccccccccccc}
\hline Treatment & DOPA & DOPEX & EPI & NOREPI & $\begin{array}{c}\text { NOREPI } \\
+ \text { DOB }\end{array}$ & $\begin{array}{c}\text { NOREPI } \\
+ \\
\text { DOPEX }\end{array}$ & $\begin{array}{c}\text { NOREPI } \\
+ \text { EPI }\end{array}$ & $\begin{array}{c}\text { NOREPI } \\
+ \text { VASO }\end{array}$ & PHENY & TERLI & VASO \\
\hline Outcome & 0.0 & 11.2 & 1.0 & 0.0 & 10.9 & 57.3 & 14.8 & 2.4 & 1.2 & 9.8 & 0.5 \\
\hline
\end{tabular}

DOPA, dopamine; DOPEX, dopexamine; EPI, epinephrine; NOREPI, norepinephrine; NOREPI + DOB, norepinephrine + dobutamine; NOREPI + DOPEX, norepinephrine + dopexamine; NOREPI + EPI, norepinephrine + epinephrine; NOREPI + VASO, norepinephrine + vasopressin; PHENY, phenylephrine; TERLI, terlipressin; VASO, vasopressin.

comparing this combination to epinephrine. Further, dopexamine is not available in many countries and has fallen out of favor. But according to our study, the results gave clinical practitioners the reference that the combination treatment could be better in downing 28-day mortality.

\section{Conclusions}

All in all, single dopamine showed significantly higher $28 \mathrm{~d}$ mortality, as well as combination regimens of vasopressors accounted for the best three therapeutic regimens. In treating patients with septic shock, using combining regimens probably gets more benefits. 


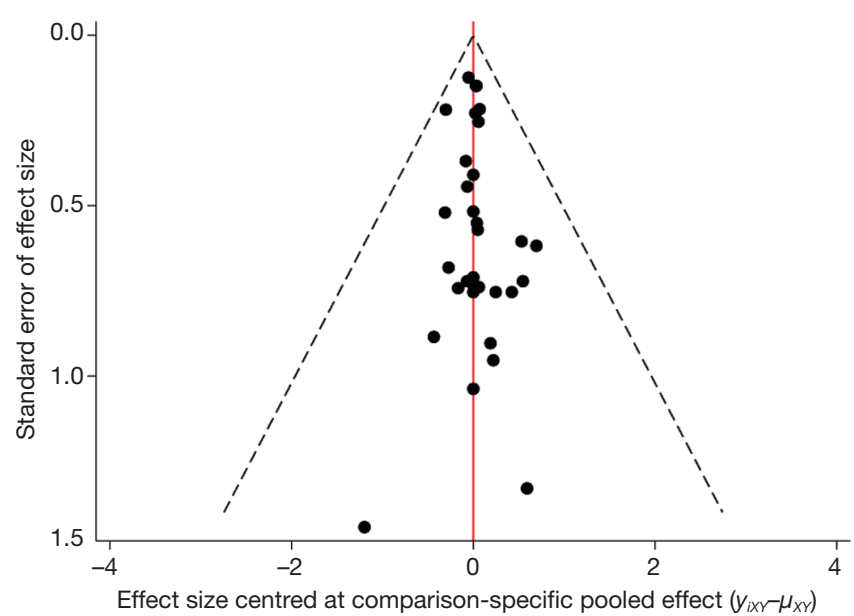

Figure 4 Funnel plot.

\section{Acknowledgments}

We acknowledge all the contributed authors.

\section{Footnote}

Conflicts of Interest: The authors have no conflicts of interest to declare.

Ethical Statement: The authors are accountable for all aspects of the work in ensuring that questions related to the accuracy or integrity of any part of the work are appropriately investigated and resolved. This study is a network meta-analysis, which does not need ethics approval. The authors are accountable for all aspects of the work in ensuring that questions related to the accuracy or integrity of any part of the work are appropriately investigated and resolved.

\section{References}

1. Seymour CW, Liu VX, Iwashyna TJ, et al. Assessment of Clinical Criteria for Sepsis: For the Third International Consensus Definitions for Sepsis and Septic Shock (Sepsis-3). JAMA 2016;315:762-74.

2. Shankar-Hari M, Phillips GS, Levy ML, et al. Developing a New Definition and Assessing New Clinical Criteria for Septic Shock: For the Third International Consensus Definitions for Sepsis and Septic Shock (Sepsis-3). JAMA 2016;315:775-87.

3. Singer M, Deutschman CS, Seymour CW, et al. The Third International Consensus Definitions for Sepsis and Septic Shock (Sepsis-3). JAMA 2016;315:801-10.
4. Martin GS, Mannino DM, Eaton S, et al. The epidemiology of sepsis in the United States from 1979 through 2000. N Engl J Med 2003;348:1546-54.

5. Angus DC, Linde-Zwirble WT, Lidicker J, et al. Epidemiology of severe sepsis in the United States: analysis of incidence, outcome, and associated costs of care. Crit Care Med 2001;29:1303-10.

6. Dellinger RP. Cardiovascular management of septic shock. Crit Care Med 2003;31:946-55.

7. Hotchkiss RS, Karl IE. The pathophysiology and treatment of sepsis. N Engl J Med 2003;348:138-50.

8. Avni T, Lador A, Lev S, et al. Vasopressors for the Treatment of Septic Shock: Systematic Review and MetaAnalysis. PLoS One 2015;10:e129305.

9. De Backer D, Aldecoa C, Njimi H, et al. Dopamine versus norepinephrine in the treatment of septic shock: a metaanalysis*. Crit Care Med 2012;40:725-30.

10. Zhou F, Mao Z, Zeng X, et al. Vasopressors in septic shock: a systematic review and network meta-analysis. Ther Clin Risk Manag 2015;11:1047-59.

11. Zhu Y, Huang H, Xi X, et al. Terlipressin for septic shock patients: a meta-analysis of randomized controlled study. J Intensive Care 2019;7:16.

12. Oba Y, Lone NA. Mortality benefit of vasopressor and inotropic agents in septic shock: a Bayesian network meta-analysis of randomized controlled trials. J Crit Care 2014;29:706-10.

13. Nagendran M, Maruthappu M, Gordon AC, et al. Comparative safety and efficacy of vasopressors for mortality in septic shock: A network meta-analysis. J Intensive Care Soc 2016;17:136-45.

14. Cheng L, Yan J, Han S, et al. Comparative efficacy of vasoactive medications in patients with septic shock: a network meta-analysis of randomized controlled trials. Crit Care 2019;23:168.

15. Li J, Wang XY, Yang ZY, et al. The efficacy of simendan in the treatment of acute heart failure and its impact on NTproBNP. Eur Rev Med Pharmacol Sci 2019;23:4027-32.

16. Hajjej Z, Meddeb B, Sellami W, et al. Effects of Levosimendan on Cellular Metabolic Alterations in Patients With Septic Shock: A Randomized Controlled Pilot Study. Shock 2017;48:307-12.

17. Alhashemi JA, Alotaibi QA, Abdullah GM, et al. Levosimendan vs dobutamine in septic shock. J Crit Care 2009;24:e14-5.

18. Morelli A, De Castro S, Teboul JL, et al. Effects of levosimendan on systemic and regional hemodynamics in septic myocardial depression. Intensive Care Med 2005;31:638-44. 
19. Meng JB, Hu MH, Lai ZZ, et al. Levosimendan Versus Dobutamine in Myocardial Injury Patients with Septic Shock: A Randomized Controlled Trial. Med Sci Monit 2016;22:1486-96.

20. Gordon AC, Perkins GD, Singer M, et al. Levosimendan for the Prevention of Acute Organ Dysfunction in Sepsis. N Engl J Med 2016;375:1638-48.

21. Morelli A, Donati A, Ertmer C, et al. Levosimendan for resuscitating the microcirculation in patients with septic shock: a randomized controlled study. Crit Care 2010;14:R232.

22. Memiş D, Inal MT, Sut N. The effects of levosimendan vs dobutamine added to dopamine on liver functions assessed with noninvasive liver function monitoring in patients with septic shock. J Crit Care 2012;27:318.e1-6.

23. Torraco A, Carrozzo R, Piemonte F, et al. Effects of levosimendan on mitochondrial function in patients with septic shock: a randomized trial. Biochimie 2014;102:166-73.

24. Fang M, Dong S. Effects of levosimendan on hemodynamics and cardiac function in patients with septic shock. Zhonghua Wei Zhong Bing Ji Jiu Yi Xue 2014;26:692-6.

25. Malay MB, Ashton RC Jr, Landry DW, et al. Low-dose vasopressin in the treatment of vasodilatory septic shock. J Trauma 1999;47:699-703; discussion 705.

26. Russell JA, Vincent JL, Kjolbye AL, et al. Selepressin, a novel selective vasopressin V1A agonist, is an effective substitute for norepinephrine in a phase IIa randomized, placebo-controlled trial in septic shock patients. Crit Care 2017;21:213.

27. Morelli A, Donati A, Ertmer C, et al. Effects of vasopressinergic receptor agonists on sublingual microcirculation in norepinephrine-dependent septic shock. Crit Care 2011;15:R217.

28. Annane D, Vignon P, Renault A, et al. Norepinephrine plus dobutamine versus epinephrine alone for management of septic shock: a randomised trial. Lancet 2007;370:676-84.

29. Baske K, Saini SS, Dutta S, et al. Epinephrine versus dopamine in neonatal septic shock: a double-blind randomized controlled trial. Eur J Pediatr 2018;177:1335-42.

30. Choudhury A, Kedarisetty CK, Vashishtha C, et al. A randomized trial comparing terlipressin and noradrenaline in patients with cirrhosis and septic shock. Liver Int 2017;37:552-61.

31. De Backer D, Biston P, Devriendt J, et al. Comparison of dopamine and norepinephrine in the treatment of shock. N Engl J Med 2010;362:779-89.

32. Gordon AC, Mason AJ, Thirunavukkarasu N, et al. Effect of Early Vasopressin vs Norepinephrine on Kidney Failure in Patients With Septic Shock: The VANISH Randomized Clinical Trial. JAMA 2016;316:509-18.

33. Gordon AC, Russell JA, Walley KR, et al. The effects of vasopressin on acute kidney injury in septic shock. Intensive Care Med 2010;36:83-91.

34. Hammond DA, Ficek OA, Painter JT, et al. Prospective Open-label Trial of Early Concomitant Vasopressin and Norepinephrine Therapy versus Initial Norepinephrine Monotherapy in Septic Shock. Pharmacotherapy 2018;38:531-8.

35. Hua F, Wang X, Zhu L. Terlipressin decreases vascular endothelial growth factor expression and improves oxygenation in patients with acute respiratory distress syndrome and shock. J Emerg Med 2013;44:434-9.

36. Jain G, Singh DK. Comparison of phenylephrine and norepinephrine in the management of dopamine-resistant septic shock. Indian J Crit Care Med 2010;14:29-34.

37. Lauzier F, Levy B, Lamarre P, et al. Vasopressin or norepinephrine in early hyperdynamic septic shock: a randomized clinical trial. Intensive Care Med 2006;32:1782-9.

38. Levy B, Bollaert PE, Charpentier C, et al. Comparison of norepinephrine and dobutamine to epinephrine for hemodynamics, lactate metabolism, and gastric tonometric variables in septic shock: a prospective, randomized study. Intensive Care Med 1997;23:282-7.

39. Luckner G, Dunser MW, Stadlbauer KH, et al. Cutaneous vascular reactivity and flow motion response to vasopressin in advanced vasodilatory shock and severe postoperative multiple organ dysfunction syndrome. Crit Care 2006;10:R40.

40. Mahmoud KM, Ammar AS. Norepinephrine supplemented with dobutamine or epinephrine for the cardiovascular support of patients with septic shock. Indian J Crit Care Med 2012;16:75-80.

41. Marik PE, Mohedin M. The contrasting effects of dopamine and norepinephrine on systemic and splanchnic oxygen utilization in hyperdynamic sepsis. Jama 1994;272:1354-7.

42. Martin C, Papazian L, Perrin G, et al. Norepinephrine or dopamine for the treatment of hyperdynamic septic shock? Chest 1993;103:1826-31.

43. Mathur SK DR, Chakraborty A. Comparison of norepinephrine and dopamine in the management of septic shock using impedance cardiography. Indian J Crit Care Med 2007;11:186-91.

44. Mehta S, Granton J, Gordon AC, et al. Cardiac ischemia in patients with septic shock randomized to vasopressin or 
norepinephrine. Crit Care 2013;17:R117.

45. Morelli A, Ertmer C, Lange M, et al. Effects of short-term simultaneous infusion of dobutamine and terlipressin in patients with septic shock: the DOBUPRESS study. Br J Anaesth 2008;100:494-503.

46. Morelli A, Ertmer C, Rehberg S, et al. Continuous terlipressin versus vasopressin infusion in septic shock (TERLIVAP): a randomized, controlled pilot study. Crit Care 2009;13:R130.

47. Morelli A, Ertmer C, Rehberg S, et al. Phenylephrine versus norepinephrine for initial hemodynamic support of patients with septic shock: a randomized, controlled trial. Crit Care 2008;12:R143.

48. Myburgh JA, Higgins A, Jovanovska A, et al. A comparison of epinephrine and norepinephrine in critically ill patients. Intensive Care Med 2008;34:2226-34.

49. Patel GP, Grahe JS, Sperry M, et al. Efficacy and safety of dopamine versus norepinephrine in the management of septic shock. Shock 2010;33:375-80.

50. Ramaswamy KN, Singhi S, Jayashree M, et al. DoubleBlind Randomized Clinical Trial Comparing Dopamine and Epinephrine in Pediatric Fluid-Refractory Hypotensive Septic Shock. Pediatr Crit Care Med 2016;17:e502-12.

51. Ruokonen E, Takala J, Kari A, et al. Regional blood flow and oxygen transport in septic shock. Crit Care Med 1993;21:1296-303.

52. Russell JA, Fjell C, Hsu JL, et al. Vasopressin compared with norepinephrine augments the decline of plasma cytokine levels in septic shock. Am J Respir Crit Care Med 2013;188:356-64.

53. Russell JA, Walley KR, Gordon AC, et al. Interaction of vasopressin infusion, corticosteroid treatment, and

Cite this article as: Chen C, Pang L, Wang Y, Wen T, Yu W, Yue X, Rong Y, Liao W. Combination era, using combined vasopressors showed benefits in treating septic shock patients: a network meta-analysis of randomized controlled trials. Ann Transl Med 2019;7(20):535. doi: 10.21037/atm.2019.09.134 mortality of septic shock. Crit Care Med 2009;37:811-8.

54. Russell JA, Walley KR, Singer J, et al. Vasopressin versus norepinephrine infusion in patients with septic shock. N Engl J Med 2008;358:877-87.

55. Schmoelz M, Schelling G, Dunker M, et al. Comparison of systemic and renal effects of dopexamine and dopamine in norepinephrine-treated septic shock. J Cardiothorac Vasc Anesth 2006;20:173-8.

56. Seguin P, Bellissant E, Le Tulzo Y, et al. Effects of epinephrine compared with the combination of dobutamine and norepinephrine on gastric perfusion in septic shock. Clin Pharmacol Ther 2002;71:381-8.

57. Seguin P, Laviolle B, Guinet P, et al. Dopexamine and norepinephrine versus epinephrine on gastric perfusion in patients with septic shock: a randomized study [NCT00134212]. Crit Care 2006;10:R32.

58. Ventura AM, Shieh HH, Bousso A, et al. Double-Blind Prospective Randomized Controlled Trial of Dopamine Versus Epinephrine as First-Line Vasoactive Drugs in Pediatric Septic Shock. Crit Care Med 2015;43:2292-302.

59. Parker MM, Shelhamer JH, Bacharach SL, et al. Profound but reversible myocardial depression in patients with septic shock. Ann Intern Med 1984;100:483-90.

60. Martin L, Derwall M, Thiemermann C, et al. [Heart in sepsis : Molecular mechanisms, diagnosis and therapy of septic cardiomyopathy]. Anaesthesist 2017;66:479-90.

61. Russell JA, Rush B, Boyd J. Pathophysiology of Septic Shock. Crit Care Clin 2018;34:43-61.

62. Rhodes A, Evans LE, Alhazzani W, et al. Surviving Sepsis Campaign: International Guidelines for Management of Sepsis and Septic Shock: 2016. Intensive Care Med 2017;43:304-77. 
Baske 2018 Epinephrine or dopamine was initiated at 0.2 or $10 \mathrm{\mu g} / \mathrm{kg} / \mathrm{min}$; after $15 \mathrm{~min}$ if shock persisted, epinephrine or dopamine was increased to 0.3 or
thereafter to 0.4 or $20 \mu \mathrm{gg} / \mathrm{kg} / \mathrm{min}$

Choudhury Terlipressin was titrated and infused at a rate of 1.3 to $5.2 \mu \mathrm{g} / \mathrm{min}$ i.e., $2-8 \mathrm{mg}$ over 24 hours; noradrenaline at a Atrial fibrillation + ventricular rate of $7.5 \mu \mathrm{g} / \mathrm{min}$ and gradually increased to maximum $\quad 1 / 42$; noradrenaline: $4 / 42$ dose of $60 \mathrm{\mu g} / \mathrm{min}$

De Backer Doses of dopamine could be increased or decreased by Only total shock data. $\begin{array}{ll}2 \mu \mathrm{g} / \mathrm{kg} / \mathrm{min} \text { and doses of norepinephrine by } & \text { Dopamine: } 207 / 858 ; \\ 0.02 \mu \mathrm{g} / \mathrm{kg} / \mathrm{min} \text {. Maximum dose for dopamine: } & \text { norepinephrine: } 102 / 821\end{array}$ $20 \mu \mathrm{g} / \mathrm{kg} / \mathrm{min}$; Maximum dose for norepinephrine $0.19 \mu \mathrm{g} / \mathrm{kg} / \mathrm{min}$

Gordon 2016 Received either vasopressin (titrated up to $0.06 \mathrm{U} / \mathrm{min}$ ) Vasopressin: 2/205; or norepinephrine (titrated up to $12 \mu \mathrm{g} / \mathrm{min}$ ) to maintain a norepinephrine: $5 / 204$ or norepinephrine (titrated up to $12 \mu \mathrm{g} / \mathrm{min}$ ) to maintan

Gordon 2010 Either low-dose vasopressin $(0.01-0.03 \mathrm{U} / \mathrm{min})$ or norepinephrine (5-15 $\mu \mathrm{g} / \mathrm{min})$

Hammond Norepinephrine monotherapy at $5 \mu \mathrm{g} / \mathrm{min}$; the dosage of norepinephrine reached $15 \mu \mathrm{g} / \mathrm{min}$ but the MAP had not Norepinephrine + achieved target

Hua 2013 Terlipressin: $1.3 \mu \mathrm{g} / \mathrm{kg} / \mathrm{h}$. Dopamine: up to $20 \mu \mathrm{g} / \mathrm{kg} / \mathrm{h}$ to No tachyarrhythmia was maintain a mean arterial pressure of $70 \pm 5 \mathrm{mmHg}$ for $48 \mathrm{~h}$ obsopressin: 93 \pm 21 ;

Jain 2010 Either norepinephrine or phenylephrine infusion titrated to achieve a target of SBP $>90 \mathrm{mmHg}, \mathrm{MAP}>75$ $\mathrm{mmHg}$, SVRI $>1,100$ dynes.s/cm5m2, $\mathrm{Cl}>2.8 \mathrm{~L} / \mathrm{min} / \mathrm{m}^{2}$ DO2I $>550 \mathrm{~mL} / \mathrm{min} / \mathrm{m}^{2}$, and VO21 $>150 \mathrm{~mL} / \mathrm{min} / \mathrm{m}^{2}$ for continuous 6

Levy 1997 Epinephrine and Norepinephrine infusions were started at $0.3 \mu \mathrm{g} / \mathrm{kg} / \mathrm{min}$ and dobutamine was infused at a fixed dose of $5 \mu \mathrm{g} / \mathrm{kg} / \mathrm{min}$ to obtain an MAP greater than $80 \mathrm{mmHg}$ with a stable or increased $\mathrm{Cl}$

Lauzier 2006 Vasopressin $(0.04-0.2 \mathrm{U} / \mathrm{min})$ : Norepinephine $(0.1-2.8 \mathrm{\mu g} / \mathrm{kg} / \mathrm{min})$ for $48 \mathrm{~h}$ to achieve MAP at or above

$\begin{array}{ll}\text { Luckner } & \text { Group 1: Vasopressin (4 IU/h), norepinephrine } \\ 2006 & \text { was adjusted for achieving } 65 \mathrm{mmHg} \text {; Group 2: }\end{array}$ was adjusted for achieving $65 \mathrm{mmHg}$; Group 2:
norepinephrine was adjusted for achieving $65 \mathrm{mmHg}$

Marik 1994 Randomized to receive an infusion of either dopamine or norepinephrine titrated to increase the MAP to greater than $75 \mathrm{mmHg}$

Mathur 2007 Dopamine: dosage range $10-25 \mathrm{mcg} / \mathrm{kg} / \mathrm{min}$ and with increments of $2.5 \mathrm{mcg} / \mathrm{kg} / \mathrm{min}$; norepinephrine: dosage range $0.5-2.5 \mathrm{mcg} / \mathrm{kg} / \mathrm{mg}$ in with increments of $0.25 \mathrm{mcg} / \mathrm{kg} / \mathrm{min}$

Martin 1993 Received either dopamine (2.5 to $25 \mu \mathrm{g} / \mathrm{kg} / \mathrm{min})$ or norepinephrine $(0.5$ to $5.0 \mu \mathrm{\mu g} / \mathrm{kg} / \mathrm{min})$

Morelli 2008 Either norepinephrine or phenylephrine infusion titration to achieve a mean arterial pressure between 65 to $75 \mathrm{mmHg}$

NA

Norepinephrin:

115.66 7.46

$150.48 \pm 12.72$

Non-arrhythmia happened (0 Epinephrine: 108 \pm 19 ; norepinephrinedobutamine: $120 \pm 15$

NA

Vasopressin: 93 \pm 21 ; norepinephrine: $96 \pm 18$

Dopamine: $139 \pm 3$; norepinephrine: $102 \pm 3$

Dopamine: $141.64 \pm 8.67$; norepnephrine:129.08 55.86

NA

New-onset tachyarrhythmias. NA Phenylephrine: 2/16; norepinephrine: 1/16

NA

NA at $70 \mathrm{mmHg}$. Terlipressin: $1 \mathrm{mg}$

Morelli 2009 Vasopressin: $0.03 \mathrm{U}$; norepinephrine: $15 \mu \mathrm{g} / \mathrm{min}$; terlipressin: $1.3 \mu \mathrm{g} / \mathrm{kg} / \mathrm{h}$ for $48 \mathrm{~h}$

New-onset tachyarrhythmias

To achieve a MAP $\geq 70 \mathrm{mmHg}$

Mahmo

Started at norepinephrine: $0.05 \mu \mathrm{g} / \mathrm{kg} / \mathrm{min}$ and increased gradually up to $0.1 \mu \mathrm{g} / \mathrm{kg} / \mathrm{min}$. Group 1: continued on dose of $3 \mathrm{\mu g} / \mathrm{kg} / \mathrm{min}$ and increased in increments of 2 up to $20 \mathrm{\mu g} / \mathrm{kg} / \mathrm{min}$. Group 2: continued on noreninephrine and epinephrine was added in a starting dose of

$0.05 \mu \mathrm{gg} / \mathrm{kg} / \mathrm{min}$ and increased in increments of 0.03 up to $0.3 \mu \mathrm{g} / \mathrm{kg} / \mathrm{min}$

Mehta 2013 Low-dose vasopressin (0.01-0.03 U/min) or NE Low-dose vasopressin (0.01-0.03 U/min) or NE Vasopressin: 4/65 $(5-15 \mathrm{\mu g} / \mathrm{min})$, titrated to maintain a mean blood pressure norepinephrine: $8 / 56$

Patel 2010 Dopamine $(5-20 \mu \mathrm{g} / \mathrm{kg} / \mathrm{min})$; norepinephrine $(5-20 \mu \mathrm{g} / \mathrm{min})$

Ruokonen The goal of the treatment was to correct the hypotension (MAP > $70 \mathrm{mmHg}$ )

Randomized to receive either dopamine (in incrementa doses, 10 to 15 to $20 \mu \mathrm{g} / \mathrm{kg} / \mathrm{min}$ ) or epinephri

Russell 2009 Vasopressin (0.01-0.03 U/min); norepinephrine $(5-15 \mu \mathrm{g} / \mathrm{min})$

Russell 2008 Randomized receiving a minimum of $5 \mu \mathrm{g}$ of norepinephrine/min to receive either low-dose vasopressin $(0.01$ to $0.03 \mathrm{U} / \mathrm{min})$ or norepinephrine (5-15 $\mathrm{\mu g} / \mathrm{min})$

Russell 2013 Vasopressin (0.01-0.03 U/min) or norepinephrine $(5-15 \mu \mathrm{g} / \mathrm{min})$ that were titrated and weaned to maintain a mean arterial presure of 65-75 $\mathrm{mmH}$

Schmoelz Dopexamine (2 $\mu \mathrm{g} / \mathrm{kg} / \mathrm{min})$; dopamine $(3 \mu \mathrm{g} / \mathrm{kg} / \mathrm{min})$

Seguin 2002 Epinephrine or norepinephrine from $0.1 \mathrm{\mu g} / \mathrm{kg} / \mathrm{min}$ with 02 pg/kg/min increses continuously infused at $5 \mathrm{\mu g} / \mathrm{kg} / \mathrm{min}$; doses of epinephrine and norepinephrine were 03.02 and epinephrine and nor

Seguin 2006 Epinephrine and norepinephrine: $0.2 \mu \mathrm{gg} / \mathrm{kg} / \mathrm{min}$ with $0.2 \mu \mathrm{g} / \mathrm{kg} / \mathrm{min}$ increments every 3 minutes; dopexam $0.5 \mu \mathrm{g} / \mathrm{kg} / \mathrm{min}$ with $0.5 \mu \mathrm{g} / \mathrm{kg} / \mathrm{min}$ increments ever (i.e., atrial fibrillation). Vasopressin: $1 / 15$ terlipressin: 0/15; norepinephrine: $4 / 15$

Dopamine: $51 / 134$ norepinephrine: 14/118

Norepinephrine + norepinephine epinephrine: $6 / 30$ ine: 1/29; dopamines

Life-threatening arrhythmia. NA Vasopressin: 7/397; norepinephrine: 6/38

Vasopressin: $93 \pm 25$; norepinephrine $96 \pm 2$ terlipressin $71 \pm 16$

Norepinephrine + dobutamine: $105 \pm 5$; epinephrine: $120 \pm 7$

NA orepinephrine: $113 \pm 18$ dopamine: $114 \pm 24$ placebo: $84.85 \pm 22.90$

Epinephrine: $113 \pm 20$;

dobutamin-

norepinephrine: 110+27

Epinephrine +

norepinephrine: $115 \pm 14$; dopexamine + epinephrine: 


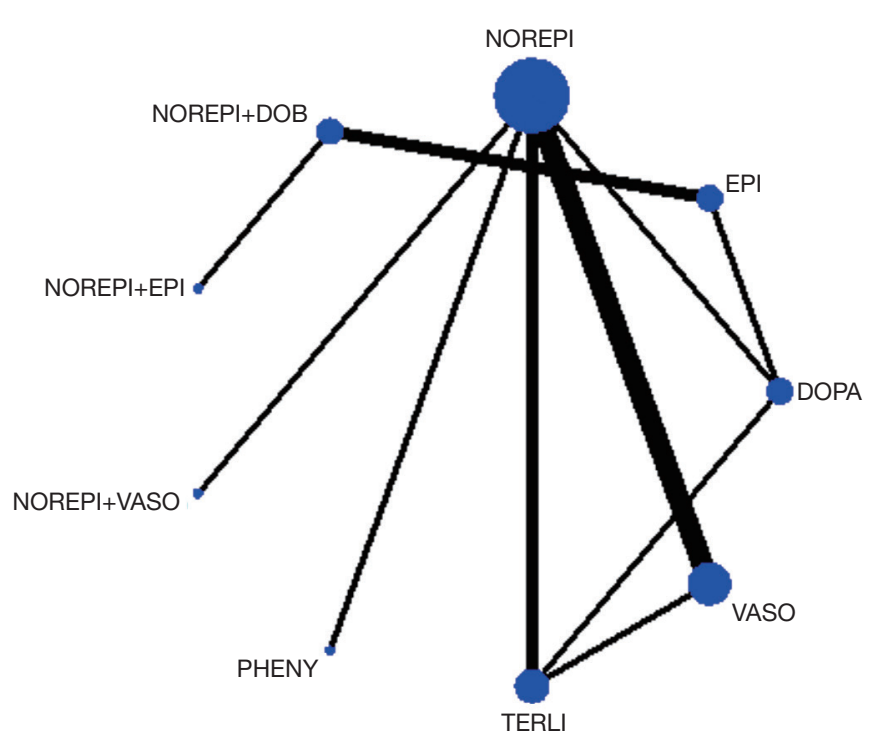

Figure S1 Network evidence of the comparisons for the different vasopressors regimens in arrhythmia.

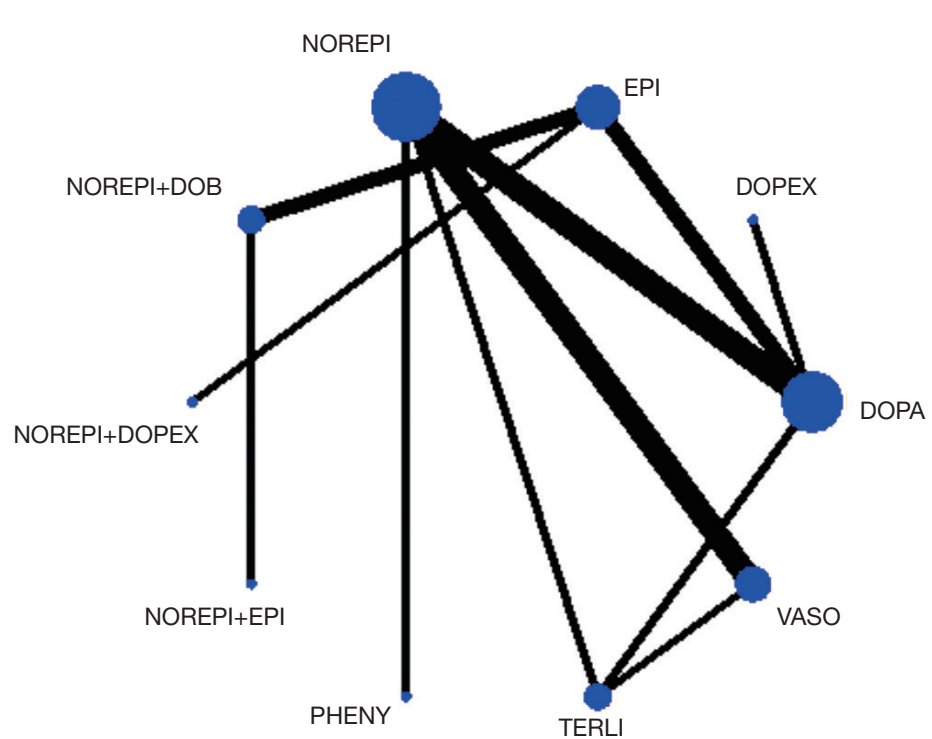

Figure S2 Network evidence of the comparisons for the different vasopressors regimens in heart rate.

Table S2 Estimated probabilities (\%) of each treatment being the best to occur arrhythmi

\begin{tabular}{|c|c|c|c|c|c|c|c|c|c|}
\hline Treatment & DOPA & EPI & NOREPI & NOREPI + DOB & NOREPI + EPI & NOREPI + VASO & PHENY & TERLI & VASO \\
\hline Outcome & 0.0 & 4.1 & 0.3 & 8.3 & 5.6 & 1.4 & 6.2 & 58.9 & 15.2 \\
\hline
\end{tabular}

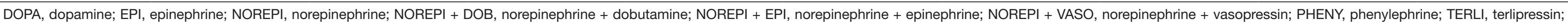
VASO, vasopressin.

Table S3 Estimated probabilities (\%) of each treatment being the best to increase heart rate

\begin{tabular}{|c|c|c|c|c|c|c|c|c|c|c|}
\hline Treatment & DOPA & DOPEX & EPI & NOREPI & NOREPI + DOB & NOREPI + DOPEX & NOREPI + EPI & PHENY & TERLI & VASO \\
\hline Outcome & 0.3 & 18.8 & 0.3 & 0.0 & 2.5 & 3.0 & 39.8 & 5.2 & 0.0 & 0.1 \\
\hline
\end{tabular}

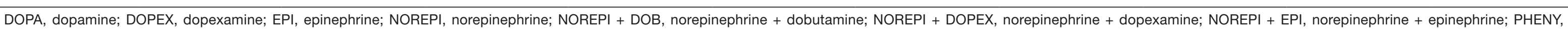
phenylephrine; TERLI, terlipressin; VASO, vasopressin.

Table S4 Odd ratios of arrhythmia in different groups

\begin{tabular}{|c|c|c|c|c|c|c|c|c|c|}
\hline Variable & A & B & C & D & E & $\mathrm{F}$ & G & $\mathrm{H}$ & I \\
\hline A & - & & & & & & & & \\
\hline B & $0.33(0.03-3.44)$ & - & & & & & & & \\
\hline C & $0.24(0.11-0.53)$ & $0.71(0.06-8.40)$ & - & & & & & & \\
\hline D & $0.30(0.03-3.37)$ & $0.91(0.50-1.65)$ & $1.27(0.10-16.05)$ & - & & & & & \\
\hline E & $0.49(0.03-7.98)$ & $1.47(0.32-6.76)$ & $2.07(0.11-37.45)$ & $1.63(0.40-6.60)$ & - & & & & \\
\hline $\mathrm{F}$ & $0.52(0.10-2.77)$ & $1.55(0.09-27.47)$ & $2.17(0.49-9.53)$ & $1.71(0.09-32.14)$ & $1.05(0.04-27.16)$ & - & & & \\
\hline G & $0.51(0.04-7.15)$ & $1.53(0.04-51.92)$ & $2.14(0.17-26.62)$ & $1.68(0.05-60.10)$ & $1.04(0.02-48.20)$ & $0.99(0.05-18.33)$ & - & & \\
\hline $\mathrm{H}$ & $0.07(0.01-0.42)$ & $0.21(0.01-3.97)$ & $0.30(0.06-1.53)$ & $0.23(0.01-4.64)$ & $0.14(0.01-3.90)$ & $0.14(0.01-1.24)$ & $0.14(0.01-2.79)$ & - & \\
\hline 1 & $0.14(0.05-0.37)$ & $0.41(0.03-5.22)$ & $0.58(0.28-1.21)$ & $0.45(0.03-6.16)$ & $0.28(0.01-5.39)$ & $0.27(0.05-1.39)$ & $0.27(0.02-3.72)$ & $1.95(0.33-11.48)$ & - \\
\hline
\end{tabular}

A, dopamine; B, dopexamine; C, epinephrine; D, norepinephrine; E, norepinephrine + dobutamine; F, norepinephrine + dopexamine; G, norepinephrine + epinephrine; H, norepinephrine + vasopressin; I, phenylephrine.

Table S5 Mean difference of heart rate in different groups

\begin{tabular}{|c|c|c|c|c|c|c|c|c|c|c|}
\hline Variable & A & B & C & $\mathrm{D}$ & $\mathrm{E}$ & $\mathrm{F}$ & $G$ & $\mathrm{H}$ & 1 & $\mathrm{~J}$ \\
\hline A & - & & & & & & & & & \\
\hline B & $13.93(-15.99-43.85)$ & - & & & & & & & & \\
\hline C & $1.60(-19.84-23.05)$ & $-12.33(-49.14-24.49)$ & - & & & & & & & \\
\hline D & $-13.60(-29.88-2.67)$ & $-27.53(-61.60-6.53)$ & $-15.21(-42.09-11.68)$ & - & & & & & & \\
\hline E & $7.04(-24.13-38.20)$ & $-6.89(-50.10-36.31)$ & $5.43(-17.20-28.06)$ & $20.64(-14.55-55.83)$ & - & & & & & \\
\hline $\mathrm{F}$ & $-4.40(-41.80-33.01)$ & $-18.33(-66.22-29.57)$ & $-6.00(-36.64-24.64)$ & $9.21(-31.56-49.98)$ & $-11.43(-49.53-26.66)$ & - & & & & \\
\hline G & $22.04(-19.69-63.76)$ & $8.11(-43.24-59.45)$ & $20.43(-15.37-56.23)$ & $35.64(-9.17-80.45)$ & $15.00(-12.74-42.74)$ & $26.43(-20.69-73.56)$ & - & & & \\
\hline $\mathrm{H}$ & $21.22(-11.28-53.71)$ & $7.29(-36.89-51.46)$ & $19.61(-19.30-58.52)$ & $34.82(6.70-62.94)$ & $14.18(-30.87-59.23)$ & $25.61(-23.92-75.14)$ & $-0.82(-53.72-52.08)$ & - & & \\
\hline । & $-22.32(-44.81-0.16)$ & $-36.25(-73.68-1.17)$ & $-23.93(-54.98-7.12)$ & $-8.72(-30.60-13.16)$ & $-29.36(-67.81-9.09)$ & $-17.93(-61.55-25.70)$ & $-44.36(-91.77-3.05)$ & $-43.54(-79.17--7.91)$ & - & \\
\hline $\mathrm{J}$ & $-12.67(-35.41-10.08)$ & $-26.60(-64.18-10.99)$ & $-14.27(-45.50-16.96)$ & $0.94(-16.31-18.19)$ & $-19.70(-58.31-18.91)$ & $-8.27(-52.02-35.48)$ & $-34.70(-82.24-12.84)$ & $-33.88(-66.87-0.89)$ & $9.66(-14.72-34.03)$ & - \\
\hline
\end{tabular}

A, dopamine; B, dopexamine; C, epinephrine; D, norepinephrine; E, norepinephrine + dobutamine; F, norepinephrine + dopexamine; G, norepinephrine + epinephrine; H, norepinephrine + vasopressin; I, phenylephrine; J, terlipressin. 